九州大学学術情報リポジトリ

Kyushu University Institutional Repository

\title{
CD146 Attenuation in Cancer-Associated Fibroblasts Promotes Pancreatic Cancer Progression
}

鄭，彪

ht tp://hdl. hand le. net/2324/1654688

出版情報 : 九州大学，2015，博士（医学），課程博士 バージョン：

権利関係：やむを得ない事由により本文ファイル非公開（2） 
氏

名：テイヒョウ

鄭彪

Zheng Biao

論 文 名：CD146 Attenuation in Cancer-Associated Fibroblasts Promotes

Pancreatic Cancer Progression

（癌関連線維芽細胞での CD146 発現減弱は膵癌進展を促進する）

区 分：甲

論文内容の要旨

癌関連線維芽細胞 (Cancer-associated fibroblast, CAF) は腫瘍の発生 ・進展に影響を与える不均一な細胞集団である。細胞膜蛋白である CD146の発現は多数の癌種で同定され、癌の進展と関与している。膵 癌の間質でもCD146 の発現がみられているが、その役割は解明され ていない。今回、我々は膵癌におけるCD146の発現とその機能につ いて検討した。まず、免疫組織化学染色を用いて膵癌切除症例におけ るCD146 発現とその臨床的意義を検討したところ、膵腫瘍内の CAF にCD146 発現を認めた。その発現は high-grade pancreatic intraepithelial neoplasia と low histological grade の浸潤性膵管癌で高レ ベルであった。また、CD146高発現の膵癌症例群は予後良好であった。 次に、人の膵癌組織由来の CAFs において CD146 発現を siRNA と plasmidを用いて抑制・過剩発現し、CAF と共培養下の癌細胞の遊走 ・浸潤能と CAF 自体の活性化に及ぼす影響を検討した。CAF の CD146 をknockdown して癌細胞と共培養すると、膵癌細胞の遊走・浸潤能を

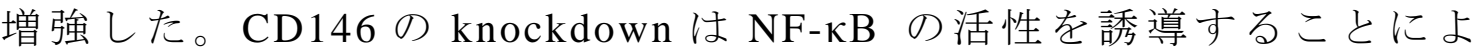
って CAF の癌間質相互作用を増強した。CAFsにCD146を過剩発現 して癌細胞と共培養すると、膵癌細胞の遊走・浸潤能を抑制した。ま た、CAFsでのCD146の発現は癌細胞との共培養によって抑制された。 今回の検討からCAFsでのCD146 発現低下は膵癌の進展を促進するこ とが示唆された。 
